Paris: Organization for European Economic Cooperation, 1961. 7 N.F.; $10 s . ; 1.75$ dollars; 5.80 D.M.). In more than thirty countries, situated in every continent, the agricultural labour force has decreased during the past ten or twenty years, when compared with total employment, although in areas in process of economic development, the agricultural population continues to grow in absolute figures; in the economically more advanced countries it is diminishing in numerical importance. In countries with an income of more than 1,000 dollars per head, less than 20 per cent of the working population is employed in agriculture; in those with an income of 500-1,000 dollars per head, about 25 per cent; and in those with a lower income, for example Italy, averaging 310 dollars, 42 per cent.

In successive chapters the report considers the adjustment of agricultural man-power resources to the needs of industry, including the reasons for leaving agriculture; the conditions of adaptation to industrial work, for example, the vocational training for industry of agricultural man-power and conditions which contribute to the satisfaction of such workers; the adaptation of rural workers to the new type of social environment; steps which facilitate adaptation to industry; and the direction of further research. Three main subjects for further research were proposed at Groningen: a special study of the conditions of adaptation of rural workers in areas in process of economic development; a general and comparative study of policies of regional development and land improvement; and somo supplementary inquiries into the adaptability of rural workers in such areas. Some indication is given of the lines these inquiries should take, and it is emphasized that investigations of this kind may facilitate social progress following the economic progress which is an integral part of industrialization.

\section{The Cawthron Institute}

The annual report for 1960-61 of the Cawthron Institute covers the Institute's fortieth year, and during the year its work was partly reorganized to include fundamental studies into some problems of world-wide occurrence and significance (Pp. 40. Nelson: Cawthron Institute, 1961). Research on the nutritional problems of fruit, tomatoes and pastures, as well as of tobacco and hops, continued in collaboration with the Tobacco and Hop Research Stations of the Department of Scientific and Industrial Research. Field investigations into factors responsible for bitter pit in apples are still concentrated on inorganic nutrients and the beneficial effect of calcium applied as a foliar spray, particularly as nitrate, has been confirmed. Biochemical research on tomatoes was directed towards a study of the poly. phenol oxidase system present with particular reference to the part of this enzyme system in blotchy ripening. In an attempt to correlate quality of tobscco with the chemical composition of the leaf, much attention has been directed to nitrogen, carbo. hydrate (particularly polysaccharides) and alkaloid fractions. A list of publications is appendod.

The Exhibition of the Institute of Physics and the Physical Society

THe forty-sixth annual exhibition of scientific instruments and apparatus, organized by the Institute of Physics and the Physical Society, will be held at the Old and New Halls of the Royal Horticultural Society, Vincent Square, London, S.W.1, during January 15-19. The exhibition has as its origin a soirée of the Physical Society in 1905, at which a few of the Fellows and their guests exhibited interesting and novel pieces of apparatus. Participation in the present exhibition is by invitation of the Council of the amalgamated Institute of Physies and Physical Society, and special efforts are now being made to ensure that the exhibition remains essentially a scientific occasion and does not become one merely for commercial displays. The 1962 exhibition will have only one hundred and eleven firms exhibiting compared with one hundred and twenty-nine in 1961, but twenty-eight academic and Government and Government-sponsored research establishments will be exhibiting, compared with seventeen in the previous year. The Institute and Society itself will this year be putting on a display of physics teaching equipment which, although in the main not original, is essentially new to Britain. Included will be some equipment designed by the American Physical Science Study Committee. The Institute and Society has published a Handbook which contains descriptions of exhibits and some new devices for which space could not be allocated in the exhibition. Besides acting as a catalogue, the Handbook will serve as a useful reference book throughout the year. Admission to the exhibition is free, but by ticket only; these and copies of the Handbook (price 6s., postage $2 s$.) are available from the Secretary, Institute of Physies and the Physical Society, 47 Belgrave Square, London, S.W.1.

\section{Announcements}

Dr. H. R. V. Arnstern, of the National Institute for Medical Research, has been appointed an honorary secretary of the Biochemical Society in succession to Dr. J. W. Whelan.

A CONFERENCE on "The Recovery of Metals" is to be held in Delft during April 25-26. Further information can be obtained from the secretary, C. M. van Baal, Laboratorium voor Metaalkunde, Rotterdamseweg 137, Delft.

A sxmposrum on "River Pollution Prevention", organized by the Institute of Sewage Purification, is to be held in Edinburgh on March 21. Further information can be obtained from Mr. James Couper, Institute of Sewage Purification, Airdrie Sewage Works, Locks Street, Coatbridge.

THE theme for the present session of the Welsh Soils Discussion Group will be "Organic Matter in Soils". A meeting will be held on February 7 at Aberystwyth to discuss "Static Aspects of Soil Organic Matter". The chairman of the meeting will be Prof. P. F. Wareing. Further information can be obtained from Mr. James A. Taylor, Geography Department, University College of Wales, Alexandra Road, Aberystwyth.

THE four hundred and twelfth meeting of the Biochemical Society will be held in the Department of Chemistry, King's College, Newcastle upon Tyne, during January 11-12. A colloquium on "Bacterial Walls and Capsules" will take place on January 11. Original communications will be presented on January 12. The Association of Clinical Biochemists will meet on January 13 in the Royal Victoria Infirmary, Newcastle upon Tyne. A symposium on "Zone Electrophoresis and Iso-enzymes" will be held in the morning, and original communications will be presented in the afternoon. 